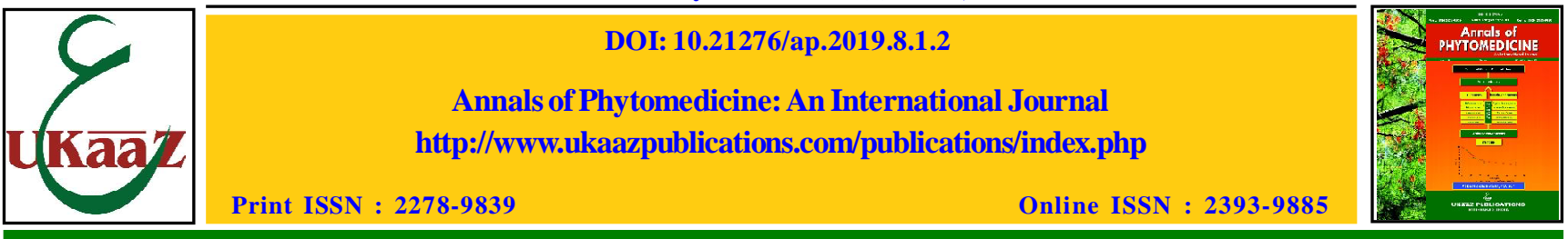

Invited article

\title{
Herbs that heal: Natural remedies for health promotion and longevity
}

\author{
Mohd Hafizur Rehman Ansari and Sayeed Ahmad \\ Bioactive Natural Product Laboratory, School of Pharmaceutical Education and Research, Jamia Hamdard, New
} Delhi-110062, India

Received April 20, 2019: Revised June 10, 2019: Accepted June 12, 2019: Published online June 30,2019

\begin{abstract}
The contemporary and traditional medical literature indicates that Emblica officinalis L. (EO), Ocimim sanctum L. (OS) and Tinospora cardifolia (Thunb.) Miers (TC) either in combination with other herbs or alone has been useful in the amelioration of colds, warts, skin afflictions, influenza, anemia, diabetes, lung conditions, elevated cholesterol and as an immune restorative in cancer conditions. Three aforesaid natural remedies are full source of phytoconstituents Vitamin C, calcium, iron, essential amino acids, tannins, polyphenols, terpenoids and many other vitamins and minerals. Regular usage of traditional herbs improves immunity, fights cancers, rejuvenates the body and age associated disorders. They have a potential to fights chronic diseases like hypertension, high cholesterol, diabetes, AIDS, influenza, chronic cough and cold, chronic infections, chronic fatigue and chronic inflammatory conditions. Ayurveda describes them as one of the best herbs for diabetes, bleeding disorders, strength, stamina promoter and others diseases.
\end{abstract}

Keywords: Herbs, medicinal plants, phytoconstituents, health and disease

\section{Introduction}

Herbs majorly utilized as a food and as well as to treat health disease from longer time. As a consistently demanding in terms of evidences, so it recognized and consumed for several potent health properties that play vital role in prevention of deleterious human diseases (Grover et al., 2015). Herbs are totally consumed as a part of spices that is already used as a medicinal property in classical system of medicine, i.e., Ayurveda, Unani and Siddha system (Sen, and Chakraborty, 2017). As far as the concern of quality, safety and efficacy, the herbal drug must be standardized by several regulations like GMP, GLP, GCP, WHO and others venerated regulations (Singh et al., 2014). In later centuries, Indians, Chinese and Egyptians are mentioned to use amla, tulsi, giloe and many other herbs as a part of traditional herbs usage in daily routine as a decoction, general tonic for health and immune boosting property, the trend was followed by other part of the world (Abhijit et al., 2016). Herbal drugs play vital role in daily health prospective from direct protection of several health associated or age associated disorders like stress, immunity, ageing (Head and Kelly, 2009). Recent, interest on herbal medication to protect the health has increased all over the world, due to less or serious side effects as compare with synthetic drugs (Rakhi et al., 2018). The most accepted evidence present in the literature referred by experimental and clinical studies, describes health promoting effects of these

\footnotetext{
Author for correspondence: Dr. Sayeed Ahmad

In Charge: Bioactive Natural Product Laboratory and

Associate Professor, Department of Pharmacognosy and Phytochemistry, School of Pharmaceutical Education and Research, Jamia Hamdard, New Delhi-110062, India

E-mail: sahmad_jh@yahoo.co.in

Tel.: +91-9891374647
}

Copyright () 2019 Ukaaz Publications. All rights reserved.

Email: ukaaz@yahoo.com; Website: www.ukaazpublications.com most valuable herbs (Biradar, 2015). These herbs have been reported to impart taste, flavor, improve digestive capability and prevent disorders (Yuan et al., 2016). However, concept of adequate herbs with specified in terms of posology, quality and quantity of specific herbs usage in single and compound formulation is still a matter of debate in Pharmacognosy (Shulammithi et al., 2016).

\section{Amla (Phyllanthus emblica Linn.)}

Amla scientifically known as Phyllanthus emblica or Emblica officinalis and utilized for several types of ailments. Amla comprises small genus and belongs to family Euphorbiaceae. It is widely cultivated in tropical and subtropical parts of India, China, Sri lanka, Indonesia and Peninsula region. Amla fruits also called as Indian gooseberry, sour in taste, cooling, laxative and diuretic (Tewani et al., 2017).

Amla is one of the remarkable and single herb already mentioned in "Charak Samhita", the Ayurvedic medicine literature (500 BC). Amla is a gift of nature to mankind. It is a indispensable part of Ayurvedic and Unani system of medicine with miraculous remedial qualities. In Sanskrit, it also called as Amalaki. Amlaki, translates as the fruit where the Goddess of Prosperity Resides or Sustainer. In Hindu religious mythology, the tree is worshipped as the Earth Mother as its fruit considered to be so nourishing as to be the nurse of mankind (Onions, 1994). As an ethno-pharmacological point of view, the fruits are beneficial in bronchitis, peptic ulcer, dermatitis, liver diseases, GIT disorder, anemia, inflammations, antiageing, antidepressant and cardiac disorders due to high content of vitamin $\mathrm{C}$ is most utilized in the scurvy treatment (Walia and Boolchandani, 2015).

The main active constituent that has substantial pharmacological activities in amla is designated by Indian scientist as "Phyllemblin". The fruit mainly rich in phyllaemblic, quercetin, gallic acid, tannins, 
flavonoids, pectin, and vitamin $\mathrm{C}$ and other notable polyphenolic compounds. Phytoconstituents including terpenoids, alkaloids, flavonoids, and tannins have been shown to possess useful biological activities (Arora et al., 2003). The leaves, fruits and bark are rich in tannins. It contains hydrolysable tannins Emblicanin A, Emblicanin B, punigluconin and pedunculagin (Ghosal et al., 1996), flavonoids Kaempferol 3-O alpha L (6" methyl) rhamnopyranoside, Kaempferol 3-O alpha L (6" ethyl) amnopyranoside (Rahman, 2007), alkaloids phyllantidine and phyllantine. Gallic acid, ellagic acid, 1-O-galloyl-beta-D-glucose, 3,6-di-O-galloyl-D-glucose, quercetin, chebulinic acid, chebulagic acid, corilagin together with isostrictinnin, were isolated from the fruit of EO (Zhang et al., 2003).

\subsection{Healing properties}

Amla protects cells against free radical damage and provides antioxidant action. Amla is used to treat skin disorders, premature ageing, respiratory infections, and premature ageing. Amla is useful in hemorrhage, dysentery, diarrhea and has therapeutic value in treating diabetes. Amla has astringent and antibacterial properties that help to prevent infection and help in the healing of ulcers. The analgesic and antipyretic activity of ethanol and aqueous extracts of EO fruits was investigated in several experimental models. Brewer's yeast induced hyperthermia model in rats was significantly reduced by a single oral dose of both extract. Both extracts showed most promising analgesic effects in terms of elicited pronounced inhibitory effect on acetic acidinduced writhing response in mice model. These findings suggested that extracts of EO fruits possessed potent antipyretic and analgesic activity (Perianayagam et al., 2004). The phenolic compounds of EO possibly be a more promising herbal drug candidate for amelioration of acute and chronic inûammation due to their modulatory action of free radicals (Bhandari and Kamdod, 2012).

\subsection{Antioxidant properties}

(Reddy et al., 2010) suggested that the amelioration of alcohol induced oxidative stress might be due to the combined effect of phytophenols such as tannins, flavonoids and vitamin C. Shivananjappa et al. (2012) demonstrated that aqueous extracts of EO have potency to modulate basal oxidative markers and enhance endogenous antioxidant defenses using a hepatocyte cell line (HepG2).

EO is used in anti-ageing, general skin care products and as sunscreen under the protection from devastating effects of free radicals, nonradicals and transition metal complex in terms of oxidative stress. Emblicannin-A and B enriched fractions of fresh juice of EO fruits were reported for antioxidant activity against ischemia reperfusion induced oxidative stress in rat heart. This study clearly showed that the antioxidant effect of EO and also indicated that the fruits of plant may exhibit a cardioprotective effect (Bhattacharya et al., 2002).

\subsection{Immunomodulatory properties}

Amla, being a rich source of vitamin $\mathrm{C}$, improves natural killer cell activity and antibody-dependent cellular cytotoxicity or as a selfantioxidant property. The lifespan of tumor-bearing mice was found to increase by $35 \%$ (Suresh and Vasudevan, 1994). The antioxidant and immunomodulatory effects of amla helped to suppress the enhanced apoptosis and DNA fragmentation caused by chromium
(Sai Ram et al., 2002). Arsenic-induced oxidative stress and apoptosis observed in thymocytes of arsenic-fed mice were prevented by co-administration of amla highlighting the fact that amla has strong immunomodulatory properties (Singh et al., 2013). EO was also reported as a radio-protective agent. EO extract was also studied as a radio-protective agent. Studies resulted that the radiation of Swiss albino mice constantly reducing the glutathione and catalase concentration in the intestines. Lipid peroxidation was also observed in the jejuna cells. These changes were not clearly showed when mice were treated with amla extract prior to irradiation (Jindal et al., 2009)

In some other reason for amla's reputation as a general energypromoting, health longevity, disease-preventing tonic may be its effect on the immune system. Most of studies have shown significant increases in white blood cell counts (leucocytes), and other measures of strengthened immunity in rodents given amla (Grover et al., 2015). In case of triphala reports suggested that EO can stimulate the neutrophil functions in the immunized albino rats (Suja et al., 2009) and in mice (Chatterjee et al., 2011).

\subsection{Antiageing properties}

Several stress induced diseases, including the process of ageing in case of skin, may be related to accumulation of oxidative free radicals in different tissues (Bhatacharya et al., 2000). EO tannoids employs a protective effect against neuroleptic induced Tardive Dyskinesia which is likely to be due to its earlier reported significant antioxidant effects in rat brain areas, including striatum (Bhatachary et al., 2000). Aqueous extract of EO showed antidepressant like activity possibly by inhibiting Monoamine oxidase A (MAO A) and gamma amino butyric acid (GABA), along with its antioxidant activity (Dhingra et al., 2012). The active tannoid principles present in EO with its antioxidant as well as NO scavenging properties, might have contributed to the observed protection against alcohol induced brain mitochondrial dysfunction (Reddy et al., 2011). A dose dependent of Anwala churna enhancement in memory scores of young and aged rats was produced. The amnesia induced by scopolamine and diazepam too was reversed. Anwala churna may proveto be a useful remedy for the management of Alzheimer's disease due to its multifarious beneficial effects such asmemory improvement, reversal of memory deficits and anticholinesterase activity (Perry et al., 2011). EO extract has a promising pharmacological effect that benefits collagen synthesis and protects againstits degradation, thus, could be used as a natural anti ageing (Chanvorachote et al., 2009) agent. A dose-dependent improvement in memory deficits was documented with amla extracts. The hydroalcoholic fruit extract of EO has been formulated as water-in-oil cream that is found effective for reducing transepidermal water loss, as observed by using Tewameter (Akhtar et al., 2012).

\subsection{Antidiabetic properties}

The hydro-alcoholic extract of EO leaves effectively normalize the impaired antioxidant status in streptozotocin-induced diabetes at dose dependent manner than the glibenclamide as a standard drug. It clearly showed rapidly protective effects against lipid peroxidation by scavenging the free radicals and reducing the risk of complications in diabetes (Nain et al., 2012). EO and an enriched fraction of Emblica tannoids are effective in delaying development of diabetic cataract in rats (Suryanarayana et al., 2007). 
In another study reports that EO treated rat showed more hypoglycemic and hypolipidemic activity than Phyllanthus acidus treated diabetic rats when the effect of orally administered aqueous extracts $(350 \mathrm{mg} / \mathrm{kg}$ body weight) of fruits of PE and Phyllanthus acidus on serum glucose, glycosylated hemoglobin, insulin, cholesterol, triglycerides, HDL-cholesterol, protein, urea and creatinine were examined in control and extract treated diabetic rats (Hasan et al., 2014).

Akhtar et al. (2011) evaluated the antihyperglycemic and lipid lowering activities of EO fruit in normal human as well as diabetic human volunteers. The results indicated a significant decrease in fasting and $2 \mathrm{~h}$ post prandial blood glucose levels on the 21 st day in both normal and diabetic subjects receiving 1, 2 or $3 \mathrm{~g}$ EO powder per day as compared with their baseline values. It clearly showed significant decreases were also observed in TC and triglycerides in both normal and diabetic volunteers on day 21 that were given either 2 or 3 g EO powder per day. Both normal and diabetic volunteers were receiving 2 or $3 \mathrm{~g}$ EO powder significantly improved high density lipoprotein (HDL) cholesterol and lowered low density lipoprotein (LDL) cholesterol levels (Akhtar et al., 2011). EO extracts not only attenuated the diabetic condition but also reversed neuropathic pain through modulation of oxidative nitrosative stress in diabetic rats (Tiwari et al., 2011). Kumar et al. (2009) investigated flavonoid rich fruit extract of EO in type II diabetes, induced diabetic neuropathy in male Sprague Dawley rats. Treatment with EO extract in diabetic rats displayed a significant increase in tail flick latency in hot immersion test and pain threshold level in hot plate test compared to control rats.

\subsection{Anticancer properties}

Aqueous extract of EO fruits at a concentration of $16.5 \mathrm{mg} / \mathrm{ml}$ was found to significantly inhibit the growth of cytotoxic L929 cells in culture. The EO extract was also found significantly reduce solid tumors induced by Dalton lymphoma ascites (DLA) cells while having only a moderate effect on ascites tumor. The aqueous extract of EO showed the anticancer potential against mouse skin tumerogenesis by reducing the number of tumor and volume and it was found to be very effective against breast cancer as well (Gaire et al., 2015).

The research concluded that flavonoids from EO hold a good prospective as nutraceutical and chemotherapeutics agents because of their antioxidant potential, no cytotoxicity and good intestinal absorptive property (Sharma et al., 2010). Chloroform soluble fraction of the ripe fruits of Amlaki containing alkaloids have both antimicrobial and cytotoxic activity (Hasan et al., 2016).

EO prevent and /or reduce the side effects of chemotherapy and radiotherapy (Dasaroju and Gottumukkala, 2014). Amla can effectively neutrilise or balancing the damaging effect of most chemical carcinogens in food and environment and, thus be of great value in chemoprevention program as well as treatment of cancer (Tewaniet al., 2017).The phytochemicals of amla have been extensively studied in tert-butyl hydroperoxide (t-BH)-induced toxicity, as has their mechanism of hepatoprotective action in human hepatocarcinoma cells (Hep G2 cell line). The hepatoprotective potential has been attributed to amla's ability to reduce lipid peroxidation and, thus cellular damage (Hiraganahalli et al., 2012). Several studies reported that amla extracts have also been shown to be effective in inhibiting the cell growth of lung, liver, cervical, ovarian, breast and colorectal cancer cell lines by producing apoptosis, thus suggesting its use as a chemotherapeutic agent in future (Mathai et al., 2015).

EO tannins impairing NF-kappaB inhibition include chebulagic acid, ellagic acid, and corilagin. All of them showed antiproliferative and proapoptotic potential against cancer cells. Same study was true for gallic acid, a product of hydrolysis of tannin, and as a major constituent of amla extract. NF-kappaB is an important survival factor in many cancers, and its inhibition leads to pervasive apoptosis (Zhao et al., 2015).

The ethanolic extract of EO exhibited more cytotoxicity potential $(88 \%)$. EO showed the highest potential and this was observed in the earlier work with the HepG2 cells (Syam et al., 2011). Even at very low dose of PE showed (20\%) dead cells (Sumalatha, 2013). Amla extract inhibits ovarian cancer (OC) cell growth both in vitro and in vivo possibly via inhibition of angiogenesis and activation of autophagy in OC. Thus, amla extract may prove useful as an alternative or adjunct therapeutic approach in helping to fight $\mathrm{OC}$ (De et al., 2013). EO exhibits anticancer activity against selected cancer cells, thus warrants further study as a possible chemopreventive and anti-invasive agent (Ngamkitidechakul et al., 2010.)

\section{Tulsi (Osimum sanctum Linn.)}

OS globally known for more than 2000 years and one of the most versatile medicinal plants, having several biological activities such as immunomodulation, antiulcer, anti-inflammation, antimicrobial, antihypertensive, cardioprotective, hepatoprotective, antidiabetic, antifertility, radio protective and anti-carcinogenesis, etc. (Venkataraman et al., 2009). It is a popular sacred plant of Indian subcontinent, also known as holy basil (Pandey and Madhuri, 2010). This plant is traditionally known for its medicinal properties. Tulsi has two varities, Green and Black also known as Ram and Krishna Tulsi respectively with similar chemical and medicinal properties. The genus has variety of species like Ocimum sanctum L.(Tulsi), O. gratissimum (Ram Tulsi), O. canum (Dulal Tulsi), O. bascilicum (Ban Tulsi), O. kilimandschricum, O. americanum, O. camphora and O.micranthum (Kulkarni et al., 2018). Basils are native to tropical Asia and are likely to have originated in India. Annual plant, usually propagated through seeds. It is widely distributed in tropical areas and found at an altitude of 1800 meters in Himalayan region (Mahajan et al., 2013). It is an erect, branched fragmented shrub with height of about $30-60 \mathrm{~cm}$ when mature plant. Leaves are simple, branched, opposite, obtuse, elliptical and have dentate margins. They are up to $5 \mathrm{~cm}$ long. Flowers are elongate raceme in close whorls and purple in color. Fruits are small and seeds are raddish yellow. Majorly planted after rainy season and harvested after few months (Kumar, 2012; Joseph, 2013). Some other valuable phytoconstituents of OS are enlisted in Table 1.

\subsection{Healing properties}

As per Ayurvedic literature, the tulsi are valuable in indigestion, constipation and intestinal parasites. The leaves are demulcent, diaphoretic and expectorant in bronchitis, cough, cold and fever. It is an insecticide, deodorizer and also has been used as laxative, stimulant, anti-inflammatory, cardiotonic and blood purifier in hepatic disorders (Singh et al., 2007; Mondal et al., 2009). The agents increase the physical endurance and the states of non-specific resistance are called anti-stress agents, i.e., adaptogens (Singh et al., 2012). Recent studies have shown that OS has a powerful 
adaptogenic property. Tulsi leaves help to prevent and reduce physical and mental stress (Das, 2006). In case of animal study, it is found that the ethanolic extract of OS helps in preventing the change in plasma level of corticosterone which is induced due to the exposure to noise stress. This indicates the antistress activity of Tulsi (Kulkarni and Adavirao, 2018).

Table 1: Chemical constituents of os

\begin{tabular}{|c|c|c|c|}
\hline Fixed oil & Essential oil & Mineral contents & Alcoholic extracts \\
\hline $\begin{array}{l}\text { Linoleic acid, Linolenic } \\
\text { acid, Oleic acid, } \\
\text { Palmitic acid, Stearic } \\
\text { acid }\end{array}$ & $\begin{array}{l}\text { Aromadendrene oxide, Benzaldehyde, } \\
\text { Borneol, Bornyl acetate, Camphor, } \\
\text { Caryophyllene oxide cis- } \alpha \text {-Terpineol, } \\
\text { Cubenol, Cardinene, D-Limonene } \\
\text { Eicosane, Eucalyptol,Eugenol, Farnesene } \\
\text { Farnesol, Furaldehyde, Germacrene, } \\
\text { Heptanol, Humulene, Limonene, } \\
\text { n-butylbenzoate, Ocimene, Oleic acid } \\
\text { Sabinene, Selinene, Phytol, Veridiflorol, } \\
\alpha \text {-Camphene, } \alpha \text { Myrcene, } \alpha \text {-Pinene, } \\
\beta \text {-Pinene, } \alpha \text {-Thujene, } \beta \text {-Guaiene, } \\
\beta \text {-Gurjunene, methyl chavicol, Linalool, }\end{array}$ & $\begin{array}{l}\text { Vitamin C, Vitamin A, Calcium, } \\
\text { Phosphorus, Chromium, Copper } \\
\text { Zink, Iron }\end{array}$ & $\begin{array}{l}\text { Aesculectin, Aesculin, } \\
\text { Apigenin, Caffeic acid, } \\
\text { Chlorogenic acid, Circineol, } \\
\text { Gallic acid, Galuteolin, } \\
\text { Isorientin, Isovitexin, } \\
\text { Luteolin, Molludistin, } \\
\text { Orientin, Procatechuic acid, } \\
\text { Stigmasterol, Urosolic acid, } \\
\text { Vanillin, Viceni, Vitexin, } \\
\text { Vanillic acid, }\end{array}$ \\
\hline
\end{tabular}

The activity of OS against some agents like Aspergillus fumigatus, Aspergillus niger, Candida albicans, Cryptococcus neoformans, Microsporum cassis, Sporotrichum schenkii, Escherichia coli, Staphylococcus aureus, Bacillus subtilis, Salmonella spp., P. vulgaris, Pseudomonas aeruginosa and Mycobacterium tuberculosis and found its activity against E. coli, Klebsiella aerogens, Vibrio spp., P. aeruginosa, cholera and S. aureus (Ahmad et al., 2001; Bano et al., 2017).

Wound breaking strength in incision wound model, epithelization period and \% wound concentration in excision wound model were showed owing to increased \% wound contraction by OS treated in wound healing effect in rat model. OS may be useful in the management of abnormal healing such as keloids and hypertropic scars (Shetty et al., 2006).

\subsection{Antioxidant properties}

A study showed that leaves, stem and inflorescence of holy basil have valuable phenolic compounds that are responsible for the antioxidant property of their extract (Hakkim et al., 2007). Lipid peroxidation play crucial role in inflammation, cancer and cardiac diseases. OS exerts potent inhibition of lipid peroxidation. Active principles of OS represent a large group of polyphenolic flavonoids (Geetha and Vasudevan, 2004). In a study by Kelm et al. (2000), the phenolic compounds like cirsimaritin, cirsilineol, apigenin, rosmarinic acid, isothymusin and isothymonin were also documented. Ethanolic extract of OS significantly increases the levels of superoxide dismutase (SOD), catalase and glutathione in the experimental model. The antioxidant capacity of (Trevisan et al., 2006) volatile oils, obtained by steam hydro-distillation from OS was evaluated using a high performance liquid chromatography (HPLC), based hypoxanthinexanthine oxidase and DPPH assays. In hypoxanthine xanthine oxidase assay, strong antioxidant capacity was evident from OS.

The effect of methanolic extract of OS. leaves in cerebral reperfusion injury as well as long-term hypoperfusion was studied by (Yanpallewar et al., 2004). OS pre-treatment $(200 \mathrm{mg} / \mathrm{kg} /$ day for 7 days) prevented reperfusion-induced rise in lipid peroxidation and superoxide dismutase. OS pre-treatment also stabilized the levels of tissue total sulfhydryl group during reperfusion.

\subsection{Immunomodulatory properties}

The seed oil of OS appears to modulate both humoral and cellmediated immune (CMI) responsiveness and these effects may be mediated by GABAergic pathways (Mahajan et al., 2013). In an experimental study, OS proved and showed increase production of antibody. Due to the release of mediators of hypersensitivity reactions and responses mediated in the target organs by OS (Mukherjee et al., 2005). Aqueous and alcoholic extracts increased haemagglutination titre in mice (Mediratta et al., 2002). Some bioactive constituents of tulsi which may possess the immunomodulatory potential could be urosolic acid, oleanolic acid and sarigenin (Surender et al., 1995).

OS aqueous extract produces a reduction in the total bacterial count and an increase in the count of neutrophil and lymphocyte and demonstrated a good phagocytic ability (Mukherjee et al., 2005), investigated the immunoregulatory profile of methanolic extract and an aqueous suspension of OS leaves to antigenic challenge of Salmonella typhosa and sheep erythrocytes by quantifying agglutinating antibodies indicated immunostimulation of humoral immunogenic response as represented by an increase in antibody titer in both the sheep and Widal erythrocyte agglutination tests as well as by cellular immunologic response represented by lymphocytosis and formation of E-rosette.

The aqueous extract of $\mathrm{OS}$ at the oral administration of doses of $100,200 \mathrm{mg} / \mathrm{kg} /$ day in rats enhances the production and count of $\mathrm{RBC}, \mathrm{WBC}$, hemoglobin and also enhanced the production of antibodies without affecting the biochemical parameters (Jeba $e t$ al., 2011).

\subsection{Antiageing properties}

In recent studies some important parameters were noted in terms of SEr (skin roughness), SEsm (skin smoothness), SEsc (skin scaliness) and Sew (skin wrinkles) of human skin. Results showed that basil extract gradual decreases in the values of (Hiroshi et al., 2008 ) roughness, smoothness, scaliness and wrinkles were observed for the formulation. The formulation showed decrease in mean values of skin smoothness in contrast to skin roughness which indicates that the formulation shows anti-ageing properties. 
Rasul and Akhtar reported that the progression in facial skin mechanical (viscoelasticity) with biochemical parameters (SOD, catalase, total protein, and ascorbic acid level) when skin was treated with water-in-oil type emulsion based cream loaded with ethanolic extract of OS seeds (Rasul and Akhtar, 2011). The reduction in malondialdehyde level was also noted in skin. The possible antiageing effect was analyzed as a feature of antioxidants markers such as quercetin, isoquercetin, kaempferol, cafleic acid, rosmarinic acid, rutin, catechin, ferulic acid, rutinoside, and apigenin present in extract (Marwat et al., 2011).

The results of catalase analysis show the ability of OS extract in neutralizing the effects of hydrogen peroxide. The results were dose-related and show a better effect at LD50 concentration. Superoxide has been implicated in reactions associated with ageing and in pathophysiological processes due to its transformation into more reactive species such as hydroxyl radical, which initiates lipid peroxidation (Guez et al., 2017).

The marked disappearance of hyaluronic acid in the skin lead to dramatic histochemical change observed in ageing skin (Farage et $a l ., 2008)$. The enzyme hyaluronidase is the key factor that controls the turnover of hyaluronic acid in human skin (Papakonstantinou et al., 2012). Therefore, the compounds which could inhibit hyaluronidase might be useful for skin ageing.

In other study, the antiageing activity was investigated by in vitro inhibition of collagenase, elastase, and hyaluronidase activities. Moreover, it also exerted the highest inhibition against matrix metallopeptidase- 1 and hyaluronidase with the inhibition of $77.7 \pm$ $9.0 \%$ and $98.1 \pm 0.1 \%$, respectively. Rosmarinic acid was found as the major compound responsible for those anti-ageing activities (Chaiyana et al., 2019).

\subsection{Antidiabetic properties}

The antidiabetic activity has been evaluated in variety of animal models but very few clinical studies have been carried out. The use of OS in the therapeutic management of diabetes mellitus is gaining a lot of importance (Mahajan et al., 2013). The valid mechanism of action of OS for its antidiabetic effect is that the extract of plant is able to activate adenylate cyclase or phosphatidylinositol, or having direct effect on pancreatic $\beta$-cell by promoting calcium entry and, thereby causing release of stored insulin (Chattopadhyay, 1993). The study of OS was observed that taking dried tulsi leaf powder, made from $2.5 \mathrm{~g}$ fresh leaves per day orally on empty stomach, could reduce the fasting glucose level up to $21 \mathrm{mg} / \mathrm{dl}$ and postprandial blood glucose by $15.8 \mathrm{mg} / \mathrm{dl}$ (Agarwal et al., 1996). Tulsi exhibits antidiabetic activity, as was revealed in one study, it was observed that aqueous extract of OS significantly lowers the blood glucose level in diabetic rats. Tulsi is also effective for metabolic syndromes, can be used as adjunct with other therapies (Suanarunsawat et al., 2014; Gandhi et al., 2016).

The possible mechanism of glucose lowering activity of OS in male mice was suggested that OS decreases the serum concentration of both cortisol and glucose and also exhibited antiperoxidative effect. Therefore, OS may potentially regulate corticosteroid induced diabetic mellitus (Gholap and Kar, 2004).

Ethanolic extract of OS significantly decreases the blood glucose, glycosylated hemoglobin and urea with a concomitant increase in glycogen, hemoglobin and protein in streptozotocin induced diabetic rats. This extracts also resulted in an increase in insulin and peptide levels and glucose tolerance (Narendhirakannan et al., 2006). Another study indicate that different fractions of OS have favorable effects in bringing down the severity of diabetes together with hepato-protectivity in alloxan induced diabetic rats model (Khan et al., 2010).

\subsection{Anticancer properties}

Ethanolic extract of OS produces a reduction in tumor size and an increase in the life expectancy of mice that have Sarcoma-180 solid tumors. This result has also been demonstrated by anticancer activity of OS in Lewis lung carcinoma (LLC) animal model. The anticancer activity of OS has been reported against human fibrosarcoma cells culture, wherein alcoholic extract of this drug induced cytotoxicity $50 \mathrm{mg} / \mathrm{ml}$ and above (Bano et al., 2017).

Administration of OS extracts showed that ethanolic extract had greater ability to reduce tumor development compared to aqueous extract. The observation is contrary to our previous study wherein the aqueous extract had more potency in the hamster buccal pouch carcinogenesis model than the ethanolic extract (Karthikeyan et al., 1999).

Oxidative stress may play a role as a common mediator of apoptosis. It is known apoptosis can be induced by accumulation of reactive oxygen intermediates (Papa and Skulachev, 1997). The excessive utilization of glutathione (GSH) in tumor cells proliferation may account for depleted levels of this nucleophilic trapping agent in livers of MCA injected mice. Treatment of mice with OS seed oil tried to revert it, however, the normal levels could not be attained (Prakash and Gupta, 2000). Another study showed that it has several phytochemicals like eugenol, rosmarinic acid, apigenin, myretenal, luteolin, carnosic acid and $\beta$-sitosterol which can prevent chemical-induced skin, liver, oral, and lung cancers (Baliga et al., 2013).

DNA laddering assay was performed on agarose gel electrophoresis. Therefore, the data obtained from this study confirms that OS leaves extract induced cell death in MCF 7 - breast cancer cell line. This work was supported by Gowri and Priya (2017). Rosmarinic acid inhibited colon cancer invasion colorectal cancer metastasis by inhibiting MMP-2 and MMP-9 activity (Utispan et al., 2019). Fresh leaf paste (topically) aqueous and ethanolic extract (orally) for their chemopreventive activity against 7,12-dimethylbenzaanthracene (DMBA) induced $(0.5 \%)$ hamster buccal pouch carcinogenesis. Incidence of papillomas and squamous cell carcinomas were significantly reduced and increased the survival rate in the topically applied tulsi leaf paste and orally (Karthikeyan et al., 1999) administered extracts to animals. Histopathological studies made on the mucosa confirmed the profound effect of the orally administered aqueous extract than other (Pattanayak et al., 2010). Tulsi leaf extract administered orally $(200 \mathrm{mg} / \mathrm{kg}$, p.o.) resulted in significant reduction in tumor volume, increase in average body weight, and survival rate of mice in antitumoral model (Monga $e t$ al., 2011).

\section{Giloe (Tinospora cardifolia (Thunb.) Miers)}

TC is a deciduous climbing shrub which belongs to the family Menispermaceae. This family consists of about 70 genus and 450 species that are found in tropical regions. It is well distributed in throughout the India and also in parts of Sri Lanka, China and 
Bangladesh. The plant is designated as Rasayana in Ayurveda and is renowned for building up the body's defense against definite infecting micro-organisms and immune system (Bharathi et al., 2018). It increases well in the tropical region, often attains a great height, and climbs up the trunks of large trees. Leaves are simple, membraneous, cordate, alternate, exstipulate, long petiolate, chordate in shape, showing multicoated reticulate venation. Stem is gray white, deeply cleft spirally and longitudinally, with the space between spotted with large rosette like lenticels. Thread like long aerial roots come up from the branches. Unisexual flowers and size basically small. Male flowers are in clusters forms and female flower are solitary. Six sepals arranged in two whorls of three each. They are obovate and membranous. Aggregate fruit is red, fleshy, with many drupelets on thick stalk with sub terminal style scars, scarlet coloured (Pathan and Ms, 2017). TC has anticancer (Meena et al., 2010) immune stimulating, nerve cell protecting, antidiabetic (Rathi et al., 2002; Bishayi et al., 2002) liver-protective and cholesterol lowering. TC also responsible for decreasing and protecting the cellular damage and tissues caused by radiation, the side effects of chemotherapy and speeding healing of diabetic foot ulcers.

Constituents isolated from TC belong to different classes such as glycosides, steroids, alkaloids, diterpenoid lactones, sesquiterpenoid, phenolics, aliphatic compounds and polysaccharides (Khan et al., 2016). Some others are tinosporone, tinosporic acid, cordifolisides A to E, syringen, berberine, giloin, gilenin, crude giloinin arabinogalactan polysaccharide, picrotene, bergenin, gilosterol, tinosporol, tinosporidine, sitosterol, cordifol, respectively (Sharma et al., 2010). Some other valuable constituents of TC are enlisted in Table 2. This family is rich source of terpenes and alkaloids (Spandana et al., 2013).

Table 2: Chemical constituents of TC

\begin{tabular}{|l|l|l|}
\hline $\begin{array}{l}\text { Phytochemical } \\
\text { class }\end{array}$ & $\begin{array}{l}\text { Part of the } \\
\text { plant }\end{array}$ & Compounds isolated \\
\hline Steroids & Stem & $\begin{array}{l}20 \beta \text {-hydroxyecdysone, } \\
\beta \text {-sitosterol, } \delta \text {-sitosterol, } \\
\text { Ecdysterone, Makisterone A, } \\
\text { Giloinstero }\end{array}$ \\
\hline Alkaloids & Stem, root & $\begin{array}{l}\text { choline, tembetarine, } \\
\text { magnoflorine, tinosporin, } \\
\text { palmetin, isocolumbin, } \\
\text { aporphine, jatrorrhizine, } \\
\text { tetrahydropalmatine, } \\
\text { berberine }\end{array}$ \\
\hline $\begin{array}{l}\text { Diterpenoid } \\
\text { lactones }\end{array}$ & Whole plant & $\begin{array}{l}\text { Columbine, Furanolactone, } \\
\text { clerodane derivatives, } \\
\text { tinosporin, tinosporides, } \\
\text { jateorine, }\end{array}$ \\
\hline Sesquiterpenoid & Stem & Tinocordifolin \\
\hline Glycosides & Stem & $\begin{array}{l}\text { Tinocordiside, } \\
\text { tinocordifolioside, } \\
\text { cordioside, syringing } \\
\text { apiosylglycoside, } \\
\text { syringing, pregnane, } \\
\text { glycoside palmatosides }\end{array}$ \\
\hline Others & $\begin{array}{l}\text { Roots, whole } \\
\text { plant }\end{array}$ & $\begin{array}{l}\text { tinosporic acid, Jatrorrhizine, } \\
\text { cordifol, giloin }\end{array}$ \\
\hline
\end{tabular}

\subsection{Healing properties}

The methanolic extracts of TC have been reported to have potential against several microbial infections. One of the most promising anti-bacterial activity of TC extracts has been assayed against (Narayanan et al., 2011) Enterobacter aerogene, Escherichia coli, Staphylococcus aureus, Klebsiella pneumoniae, Proteus vulgaris, Salmonella typhi, Shigella fiexneri, Salmonella paratyphi, Salmonella typhimurium, Pseudomonas aeruginosa, and Serratia marcesenses (Gram-positive bacteria) (Saha and Ghosh, 2012). In mice models, TC extract has been reported to function in bacterial clearance and improved phagocytic and intracellular bactericidal capacities of neutrophils. TC extract has been reported of immune-stimulant properties on macrophages (Sengupta et al., 2011)

In vivo administration of alcoholic extract of $\mathrm{TC}$ has been reported to increase macrophages in bone-marrow (BMDM) in bearing Dalton'slymphoma (DL) (Singh et al., 2006). In study of polyherbal preparations, Caps HT2 of TC could reduce plasma recalcifcation time an enhanced the release of lipoprotein lipaseenzyme. Other polyherbal preparation HP-1 has hepato-curative andanti-oxidant effects (Jeyachandran et al., 2003)

\subsection{Antioxidant properties}

TC extract has been reported of its strong free radical scavenging properties against superoxide anion, hydroxyl radicals $(\mathrm{OH}), \mathrm{NO}$ radical, and peroxynitriteanion $\left(\mathrm{ONOO}^{-}\right)$. TC extract was also found to reduce the toxic side effects of cyclophosphamide in mice by the free radical formation (Rawal et al., 2004). TC aqueous extract has a radio-protective enhancing the survival of mice against a sublethal dose of gamma radiation (Kapur et al., 2010). Antioxidant activity and amelioration of cyclophosphamide induced toxicity has been reported. This study showed the amelioratic effect in aflotoxicosis of duck (Sinha et al., 2004).

Methanolic extract of TC stem part of plant have been reported to anti-oxidant activity, by increasing the erythrocytes membrane catalase and lipid peroxide activity. It also decreases the activity of SOD, GPx in alloxan induced diabetic rats model (Stanely and Menon, 2003). TC alkaloids showed protection against aflatoxin induced nephrotoxicity (Gupta and Sharma, 2011).

\subsection{Immunomodulatory properties}

Guduchi's immunumodulatory property as an adjuvant therapy in diabetic patients with foot ulcers has been reported successfully. Its prospective double blind randomized controlled study showed significant improvement in wound healing. The TC extracts have potential use as an immune-prophylactic to prevent diseases in finfish aquaculture (Sudhakaran et al., 2006; Purandare and Supe, 2007).

The aqueous and alcoholic extracts of TC are reported to have beneficial effects on the immune system and have been tested successfully for their immunomodulatory activity.The degradation of proteins are assessed by sodium dodecyl sulfate-polyacrylamide gel electrophoresis (SDS-PAGE) was effectively reduced by simultaneous treatment with G1-4A/ PPI (partially purified immunomodulator) from TC during photosensitization (Upadhyay et al., 2010). TC reported to function by boosting the phagocytic activity of macrophages, production of reactive oxygen species (ROS) in human neutrophil cells, enhancement in nitric oxide (NO) 
production by stimulation of splenocytes and macrophages indicative of anti-tumor effects (Upadhyaya et al., 2011; More and Pai, 2012).

A large variety of compounds of TC which are responsible for immunomodulatory and cytotoxic effects are 11-hydroxymuskatone, $\mathrm{N}$-methyle-2-pyrrolidone, $\mathrm{N}$-formylannonain, cordifolioside A, magnoflorine, tinocordioside and syringin (Sharma et al., 2012). The novel $(1,4)$-alpha-D-glucan derived from the plant activates, the immune system through the activation of macrophages via TLR6 signaling, NF-kappaB translocation and cytokine production (Nairet al., 2006.). Administration of dose of TC ( $200 \mathrm{mg} / \mathrm{kg}$ body weight $)$ 1 hour before irradiation showed recovery of spleen weight from $49 \%$ of control in irradiated group to $93 \%$; apoptosis, from $19 \%$ to $2.8 \%$; DNA fragmentation, from $43 \%$ to $20.4 \%$; macrophage adherence, from $75 \%$ of control to $120 \%$; and macrophage spread size, from $8 \mu$ to $15 \mu$. It also stimulated proliferation in splenocytes in a dose-dependent manner (Purandare et al., 2007).

\subsection{Antiageing properties}

Rasayana are known as free-radical scavengers (Kapoor et al., 2009). Similarly, TC and PE individually have also shown significantly high DPPH-free-radical scavenging activity $(93 \%$ and $85 \%$, respectively) at $0.1 \mathrm{mg} / \mathrm{ml}$ concentration. The free radical scavenging effects of Vayasthapana Rasayana (VRF) was more than standard ascorbic acid ( $84 \%$ at $0.1 \mathrm{mg} / \mathrm{ml}$ concentration). Also, the IC50 values of VRF and standard ascorbic acid showed a huge forbidden gap $(5.51 \mu \mathrm{g} / \mathrm{ml}$ for VRF and $39 \mu \mathrm{g} / \mathrm{ml}$ for standard), clearly indicating that the formulation is more potent in scavenging free radicals in vitro. This study has validated the potential use of VRF as an antioxidant to fight age-related problems (Mukherjee et al., 2011).

An aqueous extract of TC has a radio-protective enhancing the survival of mice against a sub-lethal dose of gamma radiation (Kapoor et al., 2010). It was effective in elevating the GSH levels, expression of the gamma-glutamylcysteine ligase and $\mathrm{Cu}-\mathrm{Zn}$ SOD genes. Aqueous extract of TC inhibited radiation mediated 2-deoxyribose degradation by inhibiting the formation of $\left(\mathrm{Fe}^{2+}\right)$-bi-piridyl complex formation to confer radio-protective effects (Goel et al., 2002).

Generation of reactive oxygen species (ROS) during metabolic reactions and other activities beyond the antioxidant potential of a biological system gives rise to oxidative stress state. This plays a vital role in ageing process, cancer, neurodegenerative diseases. This concept is supported by increasing evidence that oxidative damage plays a crucial role in the development of chronic, age-related degenerative diseases, and that dietary antioxidants oppose this and lower risk of disease (Dua and Srivastava, 2015).

\subsection{Antidiabetic properties}

The aqueous, alcoholic and chloroform extracts of the TC has significant hypoglycemic potential, which is postulated to be an insulin like action and it has no significant hypolipidaemic effects (Wadood et al., 1992). Herbo-mineral formulation "Hyponid" is reported for its possible antioxidant and hypoglycemic activity. The alcoholic extract significantly reduces the blood and urine glucose and body weight, and lipids in serum and tissues in alloxan induced diabetic rats in experimental model (Stanely et al., 2000; Rathi et al., 2002).
The root extract has been reported to anti-diabetic properties which reducing the level of glycosylated haemoglobin, vitamin $\mathrm{E}$ and hydroperoxidase (Umamaheshwari et al., 2007).

The TC has been reported to mediate its anti-diabetic potential through mitigating oxidative stress (OS), stimulating insulin secretion and also by inhibiting gluconeogenesis and glycogenolysis. Alkaloids, cardiac glycosides, tannins, flavonoids, saponins, and steroids as the major phytoconstituents of TC have been reported to play an antidiabetic role (Sangeetha et al., 2011; Sudha et al., 2011).

Various studies demonstrated that amelioration of experimental diabetic neuropathy and gastropathy in rats (Grover et al., 2002), reduction of blood sugar in alloxan induced hyperglycemic rats and rabbits (Raghunathan and Sharma, 1969), significant reduction in blood glucose and lipids in brain (Dhaliwal, 1999), increase in glucose tolerance in rodents (Upadhyay et al., 2010), increase in glucose metabolism, inhibitory effect on adrenaline induced hyperglycemia by pyrrolidine derivative (Grover et al., 2000; Stanely et al., 2000), and significant hypoglycemic effect in normal and alloxan induced diabetic rabbits following administration of TC.

An Ayurvedic compound formulation Transina (TR) was studied for hyperglycaemia and superoxide dismutase (SOD) activity of pancreatic islet cells. The result indicates that the earlier reported antihyperglycaemia activity of streptozotocin (STZ) being the consequence of decrease in islet SOD activity, leading to the accumulation of degenerative oxidative free radicals in islet $\beta$-cells (Bhattacharya et al., 1997). Berberine is reported to be highly effective for curing human diabetes. It lowers elevated glucose level as effectively as metformin. It also improves hepatic metabolism during insulin resistance and metabolic syndrome by inhibiting FOXO1 gene which integrates mitochondrial function with insulin signaling (Zhang et al., 2008). Another compounds tinosporin, isocolumbin, palmatine, tinocordiside, cordioside and $\beta$-sitosterol compounds present in stem and root are also reported to possess antidiabetic, antihyperlipidemic and antioxidant properties (Sharma et al., 2015).

The present study clearly showed that TC has significant $(p<$ 0.05 ) antidiabetic activity in diabetic animals and has an efficacy of $40 \%$ to $80 \%$ compared to insulin. The administration of TC in diabetic animals did not show any increase in serum insulin levels or regeneration of pancreatic $\beta$ cells but showed increased hepatic glycogen synthase and decreased glycogen phosphorylase activity (Puranik et al., 2009).

\subsection{Anticancer properties}

TC extract have been shown to have pre-treatment of HeLa cells with decrease the cell, viability, increase LDH and decrease in GSHS-transferase activity (Rao and Rao., 2010). Dihydrotestosterone (DHT) has been reported to stimulate the growth and proliferation of Human LNCaP cells which are androgen-sensitive human prostate adenocarcinoma cells act via androgen receptor (Kapur et al., 2009).

Aerial part of TC extract has potent chemopreventive effect against cancer, in which oxidative stress plays an important causative role. Methylene chloride extract is more potent than the methanol and aqueous extracts in preventing the cell killing in cultured HeLa cells (Singhet al., 2006). Dichloromethane extracts of TC showed cytotoxic effects, showing to lipid peroxidation and release of LDH 
and decline in GST (Jagetia and Rao, 2006).The effect of TC has been reported better than doxorubic in treatment (Jagetia et al., 1998). IP injection of the alcoholic extract of TC has been shown to Dalton's lymphoma (DL) bearing mice stimulated macrophage functions like antigen-presenting ability, phagocytosis and secretion of interleukin-1 (IL-1), tumour necrosis factor (TNF) and reference nutrient intake (RNI) as well as slowed tumor growth and increased life-span of the tumor bearing host (Singh et al., 2005). TC has been reported in several other tumor models including Ehrlich ascites carcinoma (EAC) in mice (Jagetia et al., 2006), compounds NII-70, isolated from TC has been found to activate the macrophages and induced production of IL-12 and TNF- $\alpha$ and antigen specific Th1 response; NII-70 also induces production of nitric oxide by macrophages and has shown therapeutic effect against leishmania infection and tumor implant in experimental animals (Upadhyaya, 1999).

In another study, the hexane fraction of TC showed significant antiproliferative activity and induction of apoptosis in EAT cells. The cells exposed to TcHf exhibit the morphological and biochemical alterations that characterize apoptosis (Thippeyswami and Salimath, 2007).

Phagocytosis is also the one of the primary step in the process of antigen uptake by macrophage leading to antigen presentation. Indeed, we observed that the antigen presenting ability of TAM obtained from mice administered with $\mathrm{TC}$ was enhanced by in vivo administration (Singh et al., 2004). Administration of palmatine of TC significantly reduced the level of LPO in mice exposed to DMBA and croton oil and subsequently decreases the incidence of skin tumor (Ali and Dixit, 2013). Aqueous fraction of TC stem has shown potent cytotoxic activity against human colon cancer cell lines, namely; Colo-205, HCT-116, A-549 and NCI-H322 (Sharma et al., 2014). Aqueous and methanolic fractions of TC stem have been found to exhibit potent cytotoxic activity against breast cancer cell lines T-47D, MCF-7 and MDA-MB-231 (Ahmad et al., 2015).

\section{Conclusion}

The natural remedies Amla, Tulsi and Giloe used traditionally for general health and longevity since long and are very common herbs used in Ayurveda, Siddha and Unani systems of medicine. Further, these have been proved scientifically for their potential healing, antioxidant, immunomodulatory, antiageing, antidiabetic and anticancer properties.

\section{Conflict of interest}

The authors declare that no conflict of interest exists in the course of conducting this research. Both the authors had final decision regarding the manuscript and the decision to submit the findings for publication.

\section{References}

Abhijit, L.M. and Sori, R.K. (2018). Evaluation of antidiabetic activity of Tinospora cardifolia in alloxan induced diabetes in albino wistar rats. International Journal of Basic and Clinical Pharmacology, 7:1382-1386

Agarwal, P.; Ravi, V. and Singh, R.B. (1996). Randomized placebo controlled single blind trial of holy basil leaves in patients with noninsulin dependent diabetes mellitus. Int. J. Clin. Pharmacol., 34:405-406.
Ahmad, I. and Beg, A.Z. (2001). Antimicrobial and phytochemical studies on 45 Indian medicinal plants against multi-drug resistant human pathogens. J. Ethnopharmacol.,74:113-123.

Ahmad, R.; Fatima, N.; Srivastava, A.N. and Khan, M.A. (2015). Anticancer potential of medicinal plants Withania somnifera, Tinospora cardifoia and Curcuma longa: A review. World Research Journal of Medicinal and Aromatic Plants, 3:47-56.

Akhtar, M.S.; Ramzan, A.; Ali, A. and Ahmad, M. (2011). Effect of Amla fruit (Emblica ofcinalis Gaertn.) on blood glucose and lipid profle of normal subjects and type 2 diabetic patients. Int. J. Food Sci. Nutr., 62:609-616.

Ali, H. and Dixit, S. (2013). Extraction optimization of Tinospora cordifolia and assessment of the anticancer activity of its alkaloid palmatine. The Scientific World Journal, 19:34-59.

Arora, S.; Kaur, K. and Kaur, S. (2003). Indian medicinal plants as a reservoir of protective phytochemicals. Teratog Carcinog Mutagen, 1:295300 .

Bhandari, P.R. and Kamdod, M.A. (2012). Emblica officinalis (Amla): A review of potential therapeutic applications. International Journal of Green Pharmacy, 6:257-269.

Baliga, M.S.; Jimmy, R.; Tilakchand, K.R.; Sunitha, V.; Bhat, N.R. and Saldanha, E. (2013). Ocimum Sanctum L (Holy Basil or Tulsi) and its phytochemicals in the prevention and treatment of cancer. Nutrition and Cancer, 65:26-35.

Bano, N.; Ahmed, A.; Tanveer, M.; Khan, G.M. and Ansari, M. (2017). Pharmacological evaluation of Ocimum sanctum. Journal of Bioequivalence and Bioavailability, 9:387-392.

Bhatachary, S.K.; Bhatacharya, D. and Muruganandam A.V. (2000). Effect of Emblica ofcinalis tannoids on a rat model of tardive dyskinesia. Indian J. Exp. Biol., 38:945-957.

Bhatacharya, A.; Ghosal, S. and Bhatacharya, S.K. (2000). Antioxidant activity of tannoid principles of Emblica ofcinalis (amla) in chronic stress induced changes in rat brain. Indian J. Exp. Biol., 38: $877-880$.

Bhattacharya, S. K.; Bhattacharya, A.; Sairam, K. and Ghosal, S. (2002). Effects of bioactive tannoid principles of emblica officinalis on ischemia reperfusion induced oxidative stress in rat heart. Phytomedicine, 9:171-174.

Bhattacharya, S.K.; Satyan, K. S. and Chakrabarti, A. (1997). Effect of Trasina, an Ayurvedic herbal formulation on pancreatic islet superoxide dismutase activity in hyperglycaemic rats, Indian J. Exp. Biol., 35:297-299.

Biradar, D.P. (2015). Medicinal plants and phytomedicines. Ann. Phytomed., 4:1-5.

Bishayi, B.; Roychowdherry, S.; Ghosh, S. and Sengupta, M. (2002). Hepatoprotective and immunomodulatory properties of Tinospora cordifolia in $\mathrm{CCl} 4$ intoxicated mature albino rats. J. Toxicol. Sci., 27:139-146.

Gasparini, C.; Celeghini, C.; Monasta. L. and and Zauli. G. (2014). NF-kappaB pathways in hematological malignancies, Cellular and Molecular Life Sciences., 71:2083-2102.

Bharathi, C.; Reddy, A.H.; Nageswari, G.; Lakshmi, B.S.; Soumya, M.; Vanisri, D.S.; Venkatappa. B. (2018). A review on medicinal properties of Tinospora cordifolia. International Journal of Scientific Research and Review, 7:585-598.

Calixto, J.B.; Campos, M.M.; Otuki, M.F. and Santos, A.R. (2004). Anti inflammatory compounds of plant origin. Part II. modulation of pro inflammatory cytokines, chemokines and adhesion molecules. Planta Med., 70:93-103. 
Chaiyana, W.; Anuchapreeda, S.; Punyoyai, C.; Neimkhum, W.; Lee, K.H.; Lin, W.H.; Lue, S.C.; Viernstein, H. and Mueller, M. (2019). Ocimum sanctum Linn. as a natural source of skin anti-ageing compounds. Industrial Crops and Products, 127:217-224.

Chanvorachote, P.; Pongrakhananon, V.; Luanpitpong, S.; Chanvorachote, B.; Wannachaiyasit, S. and Nimmannit, U. (2009). Type I pro collagen promoting and anti collagenase activities of Phyllanthus emblica extract in mouse fbroblasts. J. Cosmet. Sci., 60:395-403.

Chatterjee, A.; Chattopadhyay, S. and Bandyopadhyay, S.K. (2011). Biphasic Effect of Phyllanthus emblica L. extract on NSAID-induced ulcer: An antioxidative trail weaved with immunomodulatory effect. Evid. Based Complement. Alternat. Med., 14:68-78.

Chattopadhyay, R.R. (1993). Hypoglycaemic effect of Ocimum sanctum leaf extract in normal and streptozotocin diabetic rats. Indian J. Exp. Biol., 31:891-893.

Das, S.K. (2006). Tulsi: The Indian holy power plant. Nat. Pdt Rad.,5:279-283.

Dasaroju, S. and Gottumukkala K.M. (2014). Current trends in the research of Emblica officinalis (Amla): A pharmacological perspective. International Journal of Pharmaceutical Sciences, 24:150-159.

De, A.; De, A.; Papasian, C.; Hentges, S.; Banerjee, S.; Haque, I.; Banerjee, S.K (2013). Emblica officinalis extract induces autophagy and inhibits human ovarian cancer cell proliferation, angiogenesis, growth of mouse xenograft tumors. PLOS ONE, 8(8):e7274.

Dhaliwal, K.S. (1999). Method and composition for treatment of diabetes. US Patent, 5886029 .

Dhingra, D.; Joshi, P.; Gupta, A. and Chhillar, R. (2012). Possible involvement of monoaminergic neurotransmission in antidepressant like activity of Emblica of cinalis fruits in mice. CNS Neurosci. Ther., 18:419-425.

Farage, M.A.; Miller, K.W.; Elsner, P. and Maibach, H.I. (2008). Intrinsic and extrinsic factors in skin ageing: a review. Int. J. Cosmet. Sci., 30: $87-95$.

Gaire, B.P.; Subedi, L. (2015). Phytochemistry, pharmacology and medicinal properties of Phyllanthus emblica Linn. Chinese Journal of Integrative Medicine, pp: 1-8

Gandhi, R.; Chauhan, B. and Jadeja, G. (2016). Effect of Ocimum Sanctum (Tulsi) powder on hyperglycemic patient. Indian J. Appl. Res., 6: 62-64.

Geetha, R.K. and Vasudevan, D.M. (2004). Inhibition of lipid peroxidation by botanical extracts of Ocimum sanctum: In vivo and in vitro studies. Life Sci.,76:21-28.

Gholap, S. and Kar, A. (2004). Hypoglycemic effects of some plant extracts are possibly mediated through inhibition in corticosteroid concentration. Pharmazie, 59:876-878.

Ghosal, S.; Tripathi, V.K. and Chauhan, S. (1996). Active constituent of Emblica officinalis: Part 1st the chemistry and antioxidant effects of two new hydrolysable tannins, emblicanin A and B. Indian J. Chem., 35:941-948.

Goel, H.C.; Prem Kumar, I. and Rana, S.V. (2002). Free radical scavenging and metal chelation by Tinospora cordifolia, a possible role in radioprotection. Indian J. Exp. Biol., 40:727-734.

Gowri, A.M. and and Priya, S. (2017). Synergistic role of food Bio molecules in cellular proliferation and Cytotoxic activity. Indian Journal of Medical Research and Pharmaceutical Sciences, 4:1-5.

Grover, H.S.; Deswal, H.; Singh, Y. and Bhardwaj, A. (2015). Therapeutic effects of amla in medicine and dentistry: A review. J. Oral. Res. Rev., $7: 65-78$
Grover, J.K.; Rathi, S.S. and Vats, V. (2002). Amelioration of experimental diabetic neuropathy and gastropathy in rats following oral administration of plant (Eugenia jambolana, Mucuna pruriens and Tinospora cordifolia) extracts. Indian J. Exp. Biol., 40:273-6.

Grover, J.K.; Vats, V. and Rathi, S.S. (2000). Anti-hyperglycemic effect of Eugenia jambolana and Tinospora cordifolia in experimental diabetes and their effects on key metabolic enzymes involved in carbohydrate metabolism. J. Ethnopharmacol., 73:461-470.

Güez, C.M.; de Souza, R.O.; Fischer,P.; de Moura Leão. M.F.; Duarte, J.A.; Boligon, A.A.; Athayde. M.L.; Zuravski, L.; de Oliveira, L.F.S. and Machado1, M.M. (2017). Evaluation of basil extract (Ocimum basilicum L.) on oxidative, antigenotoxic and anti-inflammatory effects in human leukocytes cell cultures exposed to challenging agents. Braz. J. Pharm. Sci., 53:1-12.

Gupta, R. and Sharma, V. (2011). Ameliorative effects of Tinospora cordifolia root extract on histopathological and biochemical changes induced by aflatoxin-b (1) in mice kidney. Toxicol Int., 18:94-98.

Hakkim, F.L.; Shankar, C.G. and Girija, S. (2007). Chemical composition and antioxidant property of holy basil (Ocimum sanctum L.) leaves, stems, and inflorescence and their in vitro callus cultures. J. Agric. Food Chemistry, 55:9109-9111.

Hasan, Md.R.; Islam, Md.N. and Islam, Md.R. (2016). Phytochemistry, pharmacological activities and traditional uses of Emblica officinalis: A review. International Current Pharmaceutical Journal, 5:14-21.

Head, K.A. and Kelly, G.S. (2009). Nutrients and botanicals for treatment of stress: Adrenal fatigue, neurotransmitter imbalance, anxiety, and restless sleep. Alternative Medicine Review, 14:114-140.

Hiraganahalli, B.D.; Chinampudur, V.C.; Dethe, S.; Mundkinajeddu,D.; Pandre, M.K.; Balachandran, J. and Aggarwal, A. (2012). Hepatoprotective and antioxidant activity of standardized herbal extracts. Pharmacogn. Mag., 8:116-123.

Hiroshi, I.; Toshihiko, K.; Hirioaki, T.; Keinji, S.; Hidetomo, S. and Masahiro, F. (2008). Combined effect of sodium chondroitin sodium hyaluronate on skin moisturization following single and repeated application. Asian J. Pharm. Sci., 3:94-101.

Jagetia, G.C. and Rao, S.K. (2006). Evaluation of the antineoplastic activity of guduchi (Tinospora cordifolia) in ehrlich ascites carcinoma bearing mice. Biol. Pharm. Bull., 29:460-466.

Jeba, C.R.; Vaidyanathan, R. and Rameshkumar, G. (2011). Immunomodulatory activity of aqueous extract of Ocimum sanctum in rat. International Journal on Pharmaceutical and Biomedical Research, 2:33-38

Jeyachandran, R.; Xavier, T.F. and Anand, S.P. (2003). Antibacterial activity of stem extracts of Tinospora cordifolia (Willd) Hook. f and Thomson. Anc. Sci. Life., 23:40-43.

Jindal, A.; Soyal, D.; Sharma, A. and Goyal, P.K. (2009). Protective effect of anextract of Emblicam offcinalis against radiation-induced damage inmice. Integr. Cancer Ther., 8:98-105.

Joseph, B. (2013). Ethanopharmacological and photochemical aspects of Ocimum sanctum Linn. The elixir of life. Brit. J. Pharma. Res., 3:273-292.

Kapoor, V.K.; Dureja, J. and Chadha, R. (2009). Herbals in the control of ageing. Drug discovery Today, 14:992-998.

Kapur, P.; Pereira, B.M.; Wuttke, W. and Jarry, H. (2009). Androgenic action of Tinospora cordifolia ethanolic extract in prostate cancer cell line LNCaP. Phytomedicine, 16:679-682.

Kapur, P.; Wutke, W.; Jarry, H. and Seidlova-Wutke, D. (2010). Beneficial effects of beta-Ecdysone on the joint, epiphyseal cartilage tissue and trabecular bone in ovariectomized rats. Phytomedicine, 17:350355 . 
Khan, M. R. I.; Islam, M. A.; Hossain, M. S.; Asadujjaman, M.; Wahed, M.I.I.; Rahman, B. M.; Anisuzzaman, A.S.M.; Shaheen, S.M. and Ahmed, M. (2010) Antidiabetic effects of the different fractions of erthanolic extracts of Ocimum sanctum in normal and alloxan induced diabetic rats. Journal of Scientific Research, 2:158-168.

Khan, Md.M.; Haque, M.S. and Chowdhury, Md.S.I. (2016). Medicinal use of the unique plant Tinospora cordifolia: evidence from the traditional medicine and recent research. Asian Journal of Medical and Biological Research, 2:508-512.

Kulkarni, K.V.; Adavirao, Dr. B.V. (2018). A review on: Indian traditional shrub Tulsi (Ocimum sanctum): The unique medicinal plant. Journal of Medicinal Plants Studies, 6:106-110.

Kumar, N.P.; Annamalai, A.R. and Thakur, R.S. (2009). Antinociceptive property of Emblica ofcinalis Gaertn (Amla) in high fat diet fed/ low dose streptozotocin induced diabetic neuropathy in rats. Indian J. Exp. Biol., 47:737-742.

Kelm, M.A.; Nair, M.G.; Strasburg, G.M. and DeWitt, D.L. (2000). Antioxidant and cyclooxygenase inhibitory phenolic compounds from Ocimum sanctum Linn. Phytomedicine., 7:7-13.

Karthikeyan, K.; Ravichandran, P. and Govindasamy, S. (1999). Chemopreventive effect of Ocimum sanctum on DMBA induced hamster buccal pouch carcinogenesis. Oral. Oncol., 35:112-119.

Kumar, P.K. (2012). Pharmacological actions of Ocimum sanctum. Review article Int. J. Advnc. Pharm. Bio. Chem., 1:406-414.

Mahajan. Rawal, N.; Verma, S.; Poddar, M.; Mayur; Alok. and Shashi. (2013). A phytopharmacological overview on Ocimum species with special emphasis on Ocimum sanctum. Biomedicine and Preventive Nutrition, 3:185-192.

Marwat, S.K.; Khan, M.S.; Ghulam, S.; Anwar, N.; Mustafa, G and Usman, K (2011). Phytochemical constituents and pharmacological activities of sweet Basil Ocimum basilicum L. (Lamiaceae). Asian Journal of Chemistry, 23:3773-3782.

Mathai, R.T.; Tonse, R.; Kalekhan, F.; Colin, M.D.; Prabhu, H.S.; Rao, S. and Baliga, M.S. (2015). Amla in the prevention of ageing: Scientific validation of the Ethnomedicinal Claims, pp:1-7.

Mediratta, P.K.; Sharma, K.K. and Singh, S. (2002). Evaluation of immunomodulatory potential of Ocimum sanctum seed oil and its possible mechanism of action. J. Ethnopharmacol., 80:15-20.

Meena, AK.; Singh, A.; Panda, P.; Mishra, S. and Rao, M.M. (2010). Tinospora cordifolia: Its bioactivities and evaluation of physicochemical properties. International Journal of Pharmacognosy and Phytochemical Research, 2:50-55.

Mondal, S.; Mirdha, B.R. and Mahapatra, S.C. (2009). The science behind sacredness of tulsi (Ocimum sanctum Linn). Ind. J. Physiol., Pharmacol., 53:292-309.

Monga, J.; Sharma, M.; Tailor, N. and Ganesh, N. (2011). Antimelanoma and radioprotective activity of alcoholic aqueous extract of different species of Ocimum in C (57) BL mice. Pharm Biol., 49:428-436.

More, P. and Pai, K. (2012). In vitro NADH-oxidase, NADPH-oxidase and myeloperoxidase activity of macrophages after Tinospora cordifolia (guduchi) treatment. Immunopharmacol Immunotoxicol., 34:368-372.

Mukherjee, R.; Dash, P. and Ram, G. (2005). Immunotherapeutic potential of Ocimum sanctum (L.) in bovine subclinical mastitis. Res. Vet. Sci., 79:37-43.

Mukherjee, S.; Pawar, N.; Kulkarni, O.; Nagarkar, B.; Thopte, S.; Bhujbal, A. and Pawar, P. (2011). Evaluation of free-radical quenching properties of standard Ayurvedic formulation Vayasthapana Rasayana. The official journal of the International Society for Complementary Medicine Research (ISCMR), 11:1-6.

Nain, P.; Saini, V.; Sharma, S. and Nain, J. (2012). Antidiabetic and antioxidant potential of Emblica officinalis Gaertn. Leaves extract in streptozotocin-induced type 2 diabetes mellitus (T2DM) rats. J. Ethnopharmacol., 142:65-71.
Nair, P.K.; Melnick, S.J.; Ramachandran, R.; Escalon, E. and Ramachandran, C. (2006). Mechanism of macrophage activation by $(1,4)$-alpha-Dglucan isolated from Tinospora cordifolia. Int. Immunopharmacol., 6:1815-1824.

Narayanan, A.S.; Raja, S.S.; Ponmurugan, K.; Kandekar, S.C.; Natarajaseenivasan, K.; Maripandi, A. and Mandeel, Q.A (2011). Antibacterial activity of selected medicinal plants against multiple antibiotic resistant uropathogens: A study from Kolli Hills, Tamil Nadu, India. Benef. Microbes., 2:235-243.

Narendhirakannan, R.T.; Subramanian, S. and Kandaswamy, M. (2006). Biochemical evaluation of antidiabetogenic properties of some commonly used Indian plants on streptozotocin-induced diabetes in experimental rats. Clin. Exp. Pharmacol. Physiol., 33:11501157.

Onions, A. (1994). Siddha Medicinal Herbs as Cosmetics Ingredients. SPC.

Pandey, G. (2010). Pharmacological activities of Osimum sanctum (Tulsi): A review. Int. J. Pharma. Sci. Rev. Res., 5:61-66.

Pandey, G. and Madhuri, S. (2010). Pharmacological activities of Ocimum Sanctum (Tulsi): A review. Int. J. Pharm. Sci. Rev. Res., 5:61-66.

Papa, S. and Skulachev, V.P. (1997). Reactive oxygen species, mitochondria, apoptosis and ageing. Mol. Cell. Biochem., 174:305-319.

Papakonstantinou, E.; Roth, M. and Karakiulakis, G. (2012). Hyaluronic acid: A key molecule in skin ageing. Dermatoendocrinology, 4:253258 .

Pathan, M.A.R. (2017). Review on Tinospora cordifolia. International Journal of Pharmaceutics and Drug Analysis, 8:310-312.

Pattanayk, P.; Behera, P.; Das, D. and Panda, S.K. (2010). Ocimum sanctum Linn. A reservoir plant for therapeutic applications: An overview. Pharmacognosy Reviews, 7:95-105.

Perianayagam, J.B.; Sharma, S.K.; Joseph, A. and Christina, A.J. (2004). Evaluation of anti pyretic and analgesic activity of Emblica ofcinalis Gaertn. J. Ethnopharmacol., 95:83-85.

Perry, E. and Howes, M.J. (2011). Medicinal plants and dementia therapy: Herbal hopes for brain aging? CNS Neurosci. Ther., 17:683-98.

Poltanov, E.A.; Shikov, A.N.; Dorman, H.J.; Pozharitskaya, O.N.; Makarov, V.G.; Tikhonov, V.P. and Hiltunan, R. (2009). Chemical and antioxidant evaluation of Indian gooseberry (Emblica officinalis Gaertn., syn. Phyllanthus emblica L.) supplements. Phytother. Res., 23:13091315.

Purandare, H. and Supe A. (2007). Immunomodulatory role of Tinospora cordifolia as an adjuvant in surgical treatment of diabetic foot ulcers: A prospective randomized controlled study. Indian J. Med. Sci., 61:347-355.

Puranik, N.; Kammar, K.F. and Devi, S. (2009). Anti-diabetic activity of Tinospora cordifolia (Willd.) in streptozotocin diabetic rats; does it act like sulfonylureas? TUBITAK. Turk. J. Med. Sci., 40:265270 .

Raghunathan, K. andd Sharma, P.V. (1969). The aqueous extract of $T$. cordifolia caused reduction of blood sugar in alloxan induced hyperglycemic rats and rabbits. J. Res. Ind. Med., 3:203-209.

Rakhi, N.K.; Tuwani, R.; Mukherjee, J. and Bagler, G. (2018). Data-driven analysis of biomedical literature suggests broad-spectrum benefits of culinary herbs and spices. PLoS One, 13:1-20.

Rao, S.K. and Rao, P.S. (2010). Alteration in the radiosensitivity of $\mathrm{HeLa}$ cells by dichloromethane extract of guduchi (Tinospora cordifolia). Integr. Cancer Ther., 9:378-384.

Rastogi, R. P. and Mehrotra. B.N (1993). Compendium of Indian Medicinal Plants. Vol - III (1980 - 1984). (Ed.), R. P. Rastogi. Publishers CDRI (Central Drug Research Institute), Lucknow and Publications and Information Directorate, New Delhi. 
Rasul, A. and Akhtar, N. (2011). Formulation and in vivo evaluation for anti-ageing effects of an emulsion containing basil extract using non-invasive biophysical techniques, DARU Journal of Pharmaceutical Sciences, 19:344-350.

Rathi, S.S.; Grover, J.K.; Vikrant, V. and Bisis, N.R. (2002). Prevention of experimental diabetic cataract by Indian Ayurvedic plant extracts. Phytother. Res., 16:774-777.

Rawal, A.; Muddeshwar, M. and Biswas, S. (2004). Effect of Rubia cordifolia, Fagonia cretica linn, and Tinospora cordifolia on free radical generation and lipid peroxidation during oxygen glucose deprivation in rat hippocampal slices. Biochem. Biophys. Res. Commun., 324:588-596.

Reddy, V.D.; Padmavathi, P.; Kavitha, G.; Gopi, S. and Varadacharyulu, N. (2011) Emblica of cinalis ameliorates alcohol induced brain mitochondrial dysfunction in rats. J. Med. Food, 14:62-68.

Reddy, V.D.; Padmavathi, P.; Paramahamsa, M. and Varadacharyulu, N.C. (2010). Amelioration of alcohol induced oxidative stress by Emblica ofcinalis (amla) in rats. Indian J. Biochem. Biophys., 47:20-25.

Rahman, H.U.; Yasin, K. A.; Choudhary, M.A.; Khaliq, N.; Rahman, A. U.; Choudhary, M.I. and Malik, S. (2007). Studies on the chemical constituents of Phyllanthus emblica. Nat. Prod. Res., 21:775 781

Saha, S. and Ghosh, S. (2012). Tinospora cordifolia: One plant, many roles. Ancient Science of Life, 4:151-159.

Sai Ram, M.; Neetu, D.; Yogesh, B.; Anju, B.; Dipti, P.; Pauline, T.;Sharma, S. K.; Sarada, S.; Ilavazhagan, G.; Kumar, D. and Selvamurthy, W. (2002). Cytoprotective and immunomodulating properties of Amla (Emblica offcinalis) on lymphocytes: An in vitro study. J. Ethnopharmacol., 81:5-10.

Sangeetha, M.K.; Balaji Raghavendran, H.R.; Gayathri, V. and Vasanthi, H.R. (2011). Tinospora cordifolia attenuates oxidative stress and distorted carbohydrate metabolism in experimentally induced type 2 diabetes in rats. J. Nat. Med., 65:544-550.

Sen, S. and Chakraborty, R. (2017). Revival, modernization and integration of Indian traditional herbal medicine in clinical practice: Importance, challenges and future. J. Tradit. Complement. Med., 7:234-244.

Sengupta, M.; Sharma, G.D. and Chakraborty, B. (2011). Effect of aqueous extract of Tinospora cordifolia on functions of peritoneal macrophages isolated from $\mathrm{CCl} 4$ intoxicated male albino mice. BMC Complement. Altern. Med., 11:1-9.

Shadia, M.; Abdel-Aziz.; Aeron, A. and Kahil, T.A. (2016). Health benefits and possible risks of herbal medicine. Springer International Publishing Switzerland, pp:97-116.

Sharma, A.K.; Kumar, S. and Pandey, A.K. (2014). Ferric reducing, anti-radical and cytotoxic activities of Tinospora cordifolia stem extracts. Biochem. Anal. Biochem., 3:1-5.

Sharma, P.; Parmar, J.; Sharma, P.; Verma, P. and Goyal, P.K. (2012). Radiationinduced testicular injury and its amelioration by T. cordifolia. An Indian medicinal plant extract. Evid. Based Comp. Altern. Med., pp:643-647.

Sharma, R.; Amin, H.; Galib. and Prajapati, P.K. (2015). Antidiabetic claims of Tinospora cordifolia (Willd.) Miers: Critical appraisal and role in therapy. Asian Pacific Journal of Tropical Biomedicine, 5:6878 .

Sharma, R.J.; Chaphalkar, S.R. and Adsool, A.D. (2010). Evaluating antioxidant potential, cytotoxicity and intestinal absorption of flavonoids extracted from medicinal plants. Int. J. Biotechnol. App., 2:01-05.
Sharma, V. and Pandey, D. (2010). Benefcial effects of Tinospora cordifolia on blood profles in male mice exposed to lead. Toxicol, Int., 17:8-11.

Shetty, S.; Udupa, S.; Udupa, L. and Somayaji, N. (2006). Wound healing activity of Ocimum sanctum Linn with supportive role of antioxidant enzymes. Indian J. Physiol. Pharmacol., 50:163-168.

Shivananjappa, M.M. and Joshi, M.K. (2012). Influence of Emblica of cinalis aqueous extract on growth and antioxidant defense system of human hepatoma cell line (HepG2). Pharm. Biol., 50:497-505.

Shulammithi, R.; Shranya, M.; Tejashwini, R and Kiranmai, R. (2016). Standardization and quality evaluation of herbal drugs. IOSR Journal of Pharmacy and Biological Sciences, 11:89-100.

Singh, E.; Sharma, S.; Pareek, A.; Dwivedi, J.; Yadav, S. and Sharma, S. (2011). Phytochemistry, traditional uses and cancer chemopreventive activity of Amla (Phyllanthus emblica): The Sustainer. Journal of Applied Pharmaceutical Science, 2:176-183.

Singh, H.P.; Sharma, S.; Chauhan, S.B. and Kaur. I. (2014). Clinical trials of traditional herbal medicines in India: Current status and challenges. International Journal of Pharmacognosy, 1:415-421.

Singh, M.K.; Yadav, S.S.; Gupta, V. and Khattri, S. (2013). Immunomodulatoryrole of Emblica offcinalis in arsenic induced oxidative damageand apoptosis in thymocytes of mice. BMC Complement. Altern. Med., 13:193.

Singh, N.; Singh, S.M.; Shrivastava, P. (2004). Immunomodulatory and antitumor actions of medicinal plant Tinospora cordifolia are mediated through activation of tumor-associated macrophages. Immunopharmacology and Immunotoxicology, 26:145-162.

Singh, N.; Verma, P.; Pandey, B.R. and Bhalla, M. (2012). Therapeutic potential of Ocimum sanctum in prevention and treatment of cancer and exposure to radiation: An overview. Int. J. Pharm. Sci. and Drug Res., 4:97-104.

Singh, R.P.; Banerjee, S; Kumar, P.V.; Raveesha, K.A. and Rao, A.R. (2006), Tinospora cordifolia induces enzymes of carcinogen/drug metabolism and antioxidant system, and inhibits lipid peroxidation in mice. Phytomedicine, 13:74-84

Singh, S. and Aggarwal, S.S. (1991). Anti-asthmatic and anti-inflammatory activity of Ocimum sanctum. International Journal of Pharmacognosy, 29:306-310.

Singh, S.; Taneja, M. and Majumdar, K.D. (2007). Biological activity of Ocimum Sanctum L. fixed oil. An overview. Ind. J. of Exp. Biology, 45:403-412.

Singh, S.M.; Singh, N. and Shrivastava, P. (2006). Effect of alcoholic extract of ayurvedic herb Tinospora cordifolia on the proliferation and myeloid differentiation of bone marrow precursor cells in a tumorbearing host. Fitoterapia, 77:1-11.

Sinha, K.; Mishra, N P.; Singh, J. and Khanuja, S.P.S. (2004). Tinospora cordifolia (Guduchi), a reservoir plant for therapeutic applications: A Review. Indian Journal of Traditional Knowledge, 3:257-270.

Spandana, U.; Ali, S.L.; Nirmala, T.; Santhi, M. and Babu, S.D.S. (2013). AReview on Tinospora cordifolia. International Journal of Current Pharmaceutical Review and Research, 4:61-68.

Suanarunsawat, T.; Ayut thaya, W.D.N.; Thirawarapan, S. and Poungshompoo, S. (2014). Anti-oxidative, anti-hyperglycemic and lipid-lowering effects of aqueous extracts of Ocimum sanctum L. leaves in diabetic rats. Food Nutr. Sci., 5:801-811.

Sudha, P.; Zinjarde, S.S.; Bhargava, S.Y. and Kumar, A.R. (2011). Potent $\alpha$ amylase inhibitory activity of Indian Ayurvedic medicinal plants. BMC Complement. Altern. Med., 11:1-10.

Sudhakaran, D.S.; Srirekha, P.; Devasree, L.D.; Premsingh, S. Michael. R.D. (2006). Immunostimulatory effect of Tinospora cordifolia Miers leaf extract in Oreochromis mossambicus, Indian J. Exp. Biol., 44:726732 . 
Suja, R.S.; Nair,A.M.C.; Sujith, S.; Preethy, J. and Deepa, A.K. (2009). Evaluation of immunomodulatory potential of Emblica officinalis fruit pulp extract in mice. Indian J. Anim. Res., 43:103-106.

Sumalatha, D. (2013). Antioxidant and antitumor activity of Phyllanthus emblica in colon cancer cell lines. International Journal of Current Microbiology and Applied Sciences, 2:189-195.

Surender, S.; Majumdar, D.K. and Singh, J.P. (1995). Studies of therapeutic efficacy of fixed oil of Ocimum sanctum in bovine mastitis. Indian Vet. J., 33:867-869.

Suresh, K. and Vasudevan, D.M. (1994). Augmentation of murine natural killercell and antibody dependent cellular cytotoxicity activities by Phyllanthus emblica, a new immunomodulator. J. Ethnopharmacol., 44:55-60.

Suryanarayana, P.; Saraswat, M.; Petrash, J.M. and Reddy G.B. (2007). Emblica officinalis and its enriched tannoids delay streptozotocin-induced diabetic cataract in rats. Mol. Vis., 13:1291-1297.

Syam, S.; Abdul, A.B.; Sukari, M.A.; Mohan, S.; Abdelwahab, S.I. and Wah T.S (2011). The growth suppressing effects of girinimbine on Hep-G2 involve induction of apoptosis and cell cycle arrest. Molecule, 16: 7155-7170.

Thippeyswami, G.; Salimath, B.P. (2007). Induction of caspase-3 activated DNase mediated apoptosis by hexane fraction of Tinospora cordifolia in EAT cells. Environmental Toxicology and Pharmacology, 23:212-220.

Tiwari, V.; Kuhad, A. and Chopra, K. (2011). Emblica ofcinalis corrects functional, biochemical and molecular deficits in experimental diabetic neuropathy by targeting the oxido nitrosative stress mediated inûammatory cascade. Phytother. Res., 25:1527-1536.

Tewani, R.; Sharma, J.K. and Rao, S.V. (2017). Indian Gooseberry (Amla) natural purgatice. International Journal of Applied Research and Technology, 2:157-164.

Trevisan, M.T.; Vasconcelos, Silva, M.G.; Pfundstein, B.; Spiegelhalder, B. and Owen, R.W. (2006). Characterization of the volatile pattern and antioxidant capacity of essential oils from different species of the genus Ocimum. J. Agric. Food Chem., 54:4378-4382.

Umamaheswari, S. and Mainzen, P.P.S. (2007). Antihyperglycaemic effects of 'IIogenExcel' an ayurvedic herbal formulation in streptozotocin induced diabetes mellitus. Acta. Pol. Pharma., 64:53-61.
Upadhyay, A.K.; Kumar, K.; Kumar, A. and Mishra, H.S. (2010). Tinospora cordifolia (Willd.) Hook. f. and Thoms. (Guduchi)-validation of the Ayurvedic pharmacology through experimental and clinical studies. Int. J. Ayurveda Res., 1:112-121.

Upadhyaya, P.R.; Sharma, V. and Anita, K.V. (2011). Assessment of the multifaceted immunomodulatory potential of the aqueous extract of Tinospora cordifolia. Res. J. Chem. Sci., 1:71-79.

Upadhyaya, S.N. (1999). Therapeutic potential of immunomodulatory compounds isolated from medicinal plants used in Ayurveda, Abstract, National Symposium on Role of Chemistry in Ayurveda (Souvenir), Banaras Hindu University, Varanasi, pp:95.

Utispan, K.; Niyomtham, N.; Yingyongnarongkul, B. and Koontongkaew, S. (2019). Ethanolic extract of Ocimum sanctum leaves reduced invasion and matrix metalloproteinase activity of head and neck cancer cell lines. The Preprint Server of biology, pp:1-18.

Venkataraman, M.; Jang-C.L.; Kwang, S.A, Hyo, J.L. and Hyo-Jeong, L. (2009). Ocimum sanctum induces apoptosis in A549 lung cancer cells and suppresses the in vivo growth of lewis lung carcinoma cells. Phytother. Res., 23:1385-1391.

Wadood, N.; Wadood, A. and Shah, S.A. (1992). Effect of Tinospora cordifolia on blood glucose and total lipid levels of normal and alloxandiabetic rabbits. Planta Med., 58:131-136.

Walia, K. and Boolchandani, R. (2015). Role of amla in Type 2 diabetes mellitus - A Review. Research Journal of Recent Sciences, 4:31-35.

Yanpallewar, S.U.; Rai, S.; Kumar, M. and Acharya, S.B. (2004). Evaluation of antioxidant and neuroprotective effect of Ocimum sanctum on transient cerebral ischemia and long-term cerebral hypoperfusion. Pharmacol. Biochem. Behav., 79:155-164.

Yuan, H.; Ma, Q.; Ye, Li. and Piao, G. (2016). The Traditional Medicine and Modern Medicine from Natural Products. Molecules, 21:1-18.

Zhang, Y.; Li, X.; Zou, D.; Liu, W.; Yang, J.; Zhu, N.; Huo, L.; Wang, M.; Hong, J.; Wu, P.; Ren, G. and Ning G. (2008). Treatment of type 2 diabetes and dyslipidemia with the natural plant alkaloid berberine. J. Clin. Endocrinol. Metab., 93:2559-2565.

Zhao, T.; Sun, Q.; Marques, M. and Witcher, M. (2014). Anticancer Properties of Phyllanthus emblica (Indian Gooseberry). Oxidative Medicine and Cellular Longevity. 